\title{
異なる発育段階のセジロウンカ卵に対する安息香酸 ベンジルの殺卵活性
}

\author{
清野 義人・鈴木 芳人 (九州農業試験場)
}

\begin{abstract}
Ovicidal activity of benzyl benzoate on different egg stages of Sogatella furcifera Horváth. Yoshito SEINo and Yoshito Suzuki (Kyushu National Agricultural Experiment Station, Nishigoshi, Kumamoto 861-11)
\end{abstract}

Susceptibility of $S$. furcifera eggs to saturated aqueous solution of benzyl benzoate (25.4ppm) was examined at $25^{\circ} \mathrm{C}$ with eggs 0 to 6 days after oviposition. Eggs immersed in the solution 0 or 1 day after oviposition suffered from $100 \%$ mortality within a day, while more than $96.7 \%$ of eggs immersed in the solution 2 to 6 days after oviposition developed normally and survived until 7 days after oviposition. The results indicated that $S$. furcifera eggs are susceptible to benzyl benzoate for less than 2 days after oviposition, before the embryo develops to the symbiont ball formation stage.

Key words: benzyl benzoate, Sogatella furcifera, ovicide, egg

セジロウンカはイネを加害する重要害虫として知られ ており，とりわけ九州では本種による産畉が水稲の幼苗 に被害を与える(清田・奥原，1990)。イネの葉鞘や葉 身中胁に産卵されたセジロウンカの卵は，正常に発育す ると $25^{\circ} \mathrm{C}$ 下で約 1 週間で㽧化する(奈須・末永，1958）。 しかし，産卵された部位のイネ組織が褐変化を起こすと 卵は発育阻害を受け，高死亡率を被ることが報告されて いる (寒川，1991)。その後の研究で，セジロウンカの 卵の高死亡率はイ亦組織の褐変化に先立つ液浸化によっ てもたらされること(鈴木ら，1993; SUZUKI et al., 1996)，さらには，イネの液浸化部位には安息香酸ベン ジルが特異的に生成され，その水溶液濃度が $6.4 \mathrm{ppm}$ 以 上にると，七ジロウンカの畉に対して殺卵活性示すこと が明らかにされている (SEINO et al., 1996)。しかし， 安息香酸ベンジルの殺卵機作についてはこれまで研究さ れていなかった。本研究ではそれを解明する手がかりを 得るため, 安息香酸ベンジルがセジロウンカの卵に対し てどの胚子発有段階で殺卵効果を示すのかを検討した。

\section{材料および方法}

\section{1. 供試した卵}

実験には1989年に福岡県筑後市で採集し，イネの牙だ し苗上で継代飼育してきたセジロウンカを用いた。イネ 幼苗に羽化後 4〜5日後の䧳成虫を 3 時間放飼した後, 幼苗を解剖して畉を採取した。採取した卵は, シャーレ
に敷いた湿った滤紙上に置き，蓋をして実験に供するま で25ㄷ下で保存した。卵の保存期間中は濾紙を湿った状 態に維持した。

\section{2. 安息香酸ベンジル飽和水溶液の作成と濃度測定}

安息香酸ベンジル (和光, 特級) $1 \mathrm{~m} \ell$ を分液ロートに 䓠留水 $50 \mathrm{~m} \ell$ と共に入れて振とうした後， $25^{\circ} \mathrm{C}$ 下に置き， 1 日後に水層を採取した。安息香酸ベンジルの水溶液濃

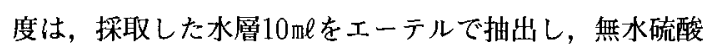
アンモニウムで脱水した後, 定容して GC で測定した。 $\mathrm{GC}$ 測定の条件は以下の通りとした：分析器, GC-14 (島津製作所製); 検出器, FID; カラム, TC-5 (GL サ イエンス社製, 内径 $0.25 \mathrm{~mm}$, 長さ $30 \mathrm{~m})$; 温度条件, $50^{\circ} \mathrm{C}$ で 1 分間保持した後 $10^{\circ} \mathrm{C} /$ 分で $300^{\circ} \mathrm{C}$ まで昇温し以後 $300^{\circ} \mathrm{C}$ で 4 分間保持; キャリアガス, ヘリウム。

\section{3. 実験方法}

安息香酸ベンジル飽和水溶液 $250 \mu \ell$ を入れだラス 瓶（内径 $1 \mathrm{~cm}$ ，長さ $4 \mathrm{~cm}$ ）を 7 本用意した。湿った滤紙 上で発育させたセジロウンカの卵から，産卵当日（産卵 後 0 日）以降 6 日後まで每日30個をとり，それをテトロ ンゴース片 $(6 \mathrm{~mm} \times 6 \mathrm{~mm})$ にのせ，ガラス瓶中の水溶液 に浸した。対照として産甽当日の30卵を同様にテトロン

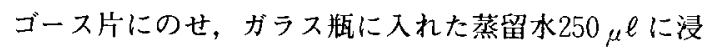
した。テトロンゴース片は, 卵を直接水溶液の入ったガ ラス瓶へ入れると内壁へくっつきやすく場合によっては 水面上に出てしまうことがあるため, 卵の内壁への移動 
の防止のために用いている。卵をいれたガラス瓶は蓋を して25号下に置いた。実験には産卵当日の卵を除き，外 見上正常に発育している畉をだけを用いた。ガラス形中 の卵の発育は産卵後 7 日まで実体顕微鏡 (40倍) 下で毎 日観察し，産卵後 7 日に眼点形成期以後の発有段階に達 した個体を生存と判定した。

\section{結}

果

$25^{\circ} \mathrm{C}$ における安息香酸ベンジル飽和水溶液蕞度は $25.4 \mathrm{ppm}$ であった。この水溶液に浸した産卵後 1 日以 前の卵の生存率は0\%であったが，産卵後 2 日の卵は $96.7 \%$ ，産卵後 3 日以後の卵は100\%生存した (Fig. 1)。 一方，産卵当日に対照として蒸留水中に浸した卵の生存 率は86.7\%であった。蒝留水に浸した卵のうち死亡した 畉は，産卵後 1 日には畉の内部が一様に白濁し，正常に 発育した透明度のある他の卵とは明らかに区別された。 卵の死亡要因は不明であるが，幼苗を解剖して取り出し た卵は湿った滤紙上に保存しても生存率は $88.7 \%(\mathrm{n}=$ 203）であったことから，卵の不受精あるいは取り出す 際に微小な傷がついたのが原因と推測される。蒸留水中 で正常に発育した卵は産卵後 2 日には卵帽基部付近に乳 白色の symbiont ball が形成され，産卵後 4 日には眼点 が前極側に形成された。これに対して，産卵当日に安息 香酸ベンジル飽和水溶液に浸した卵は，全て産卵後 1 日 には内部が一様に白濁し死亡した。産卵後 1 日に浸した 卵も産卵後 2 日には全て内容が白濁し死亡しているのが 観察された。これに対して，前極側に symbiont ball が

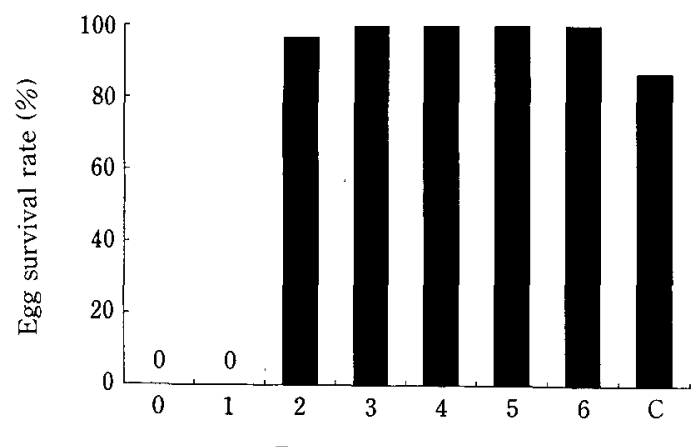

Days after oviposition

Fig. 1. Survival of $S$. furcifera eggs immersed in aqueous solution saturated with benzyl benzoate (25.4ppm). Eggs were kept on wet filter paper at $25^{\circ} \mathrm{C}$ until immersed in the solution. Control eggs $(\mathrm{C})$ were immersed in distilled water on the day of oviposition.
形成された産卵後 2 日の卵を安息香酸ベンジル飽和水溶 液に浸した結果は，1则を除き蒸留水中で発育させた卵 と同様に正常に発青し，産卵後4 日浽眼点を形成した。 産卵徯 3 日以降に安息香酸ベンジル飽和水溶液に浸した 卵の発育についても異常は認められなかった。

\section{考察}

$25.4 \mathrm{ppm}$ の安息香酸ベンジル水溶液に，産卵直後の セジロウンカの卵を浸すと100\%死亡することはすでに 報告されている (SEINo et al., 1996)。本研究ではさら に産畉後 1 日にこの濃度の水溶液に卵を浸しても100\% 死亡することが明らかになった。さらに蒸留水中で正常 に発有している卵との比較により，産卵当日と産卵後 1 日に安息香酸ベンジル飽和水溶液に浸した卵は，浸漬後 1 日以内に死亡することが示された。しかし，産卵後 2 日以降に浸漬した卵は大部分が正常に発育したので，安 息香酸ベンジルの殺卵活性は産卵後 2 日以内の卵に限定 されると結論できる。

奈須・末承 (1958) はセジロウンカの卵の発育過程を 大きく 5 段階に分類しており，この分類に従えば，卵が 安息香酸ベンジルの殺卵効果を受ける時期は肧带期以前 である。胚帯期は産卵時に卵の後極に存在した共生微生 物が，胚船の卵の中央への陷入に伴い，前極へ移動する 時期である。産卵後 2 日は共生微生物が前極の卵帽下に 止まり，肧帯が器官分化を開始する黄玟形成初期にあた り，この発育段階に達した卵は安息香酸ベンジルに対す る感受性が失われることが示惨された。卵の発育に伴う 安息香酸ベンジルに対する感受性の消失が, symbiont ball を形成する共成微生物の畍内での增殖によるのか， それとも胚子発育に伴う器官形成により体内に安息香酸 ベンジルの代謝機能が備わるためであるのかは今後の課 題である。

\section{引用文献}

1）奈須壮兆・末永一（1958）九州農試彙報 $5: 71-84$ 2）鈴木苊人·寒川一成・清田洋次 (1993) 九病虫研会報 39 : 78-81. 3) Suzuki, Y., SEino, Y. and SogAWA, K. (1996) Appl. Entomol. Zool. 31：111-118. 4) 清田洋次·奥原國 英（1990）九病虫研会報 $36: 95-96$ 5) 寒川一成 (1991) 九農研 $53: 92$. 6) SEINO, Y., SuZUKI, Y, and SOGAWA, K. (1996) Proceedings of the International Workshop on Pest Management Strategies in Asian Monsoon Agroecosystems : 89-99.

(1996年 5 月 2 日 受領) 